B. V. Vynohradov ${ }^{1}$, Dr. Sc. (Tech.), Prof., orcid.org/0000-0002-9600-0739, V.I. Samusya ${ }^{2}$, Dr. Sc. (Tech.), Prof., orcid.org/0000-0002-6073-9558, D. L. Kolosov' ${ }^{2}$, Dr. Sc. (Tech.), Assoc. Prof., orcid.org/0000-0003-0585-5908
1 - State Higher Educational Institution "Ukrainian State University of Chemical Technology", Dnipro, Ukraine, e-mail: borvvin@gmail.com

2 - Dnipro University of Technology, Dnipro, Ukraine, e-mail:vsamusya@gmail.com, evolyuta@gmail.com

\title{
LIMITATION OF OSCILLATIONS OF VIBRATING MACHINES DURING START-UP AND SHUTDOWN
}

Purpose. Development and justification of a method for limiting resonance vibrations during start-up and shutdown of vibrating machines by using cord-reinforced rubber air springs as elastic elements

Methodology. Viscoelastic models of two systems are considered; the first includes a rubber-cord air spring filled with compressed air and connected to an additional air volume through an orifice plate; the second system incorporates a rubber-cord air spring filled with liquid and connected to a hydropneumatic accumulator through an orifice plate. For these viscoelastic systems, linearized equivalent dynamic diagrams have been presented and differential equations of motion have been formulated. A method of limiting resonance vibrations during the start-up and shutdown of vibrating machines is considered. The effectiveness of limiting the resonance vibrations and forces transmitted to the fixed support structures is studied using the example of a vibrating screen. The worst case is considered when resonance vibrations are of a steady nature. The amplitude-frequency response and coefficients have been obtained, which characterize the dynamic load transmission to the fixed support structures for various viscous resistance forces determined by the orifice plate parameters.

Findings. Equivalent schematic diagrams of viscoelastic systems incorporating rubber-cord air springs and a mathematical model describing the forced vibrations have been developed, a method has been proposed for limiting vibrations and loads transmitted to the fixed support structures during start-up and shutdown of vibrating machines. The effectiveness of the proposed method has been justified.

Originality. It has been scientifically justified that the use of rubber-cord air springs as elastic elements of vibrating machines allows effectively limiting resonance vibrations and dynamic loads transmitted to the structures of fixed supports.

Practical value. This allows limiting resonance vibration amplitude of a vibrating screen and decreasing dynamic loads transmitted to the fixed support structures of vibrating machines.

Keywords: vibrating machine, rubber-cord air spring, viscoelastic system, resonance vibrations, vibration protection

Introduction. Vibrating machines such as vibrating mills, conveyors, screens, feeders, and others have found application in various industries. The stiffness of the elastic supports of the vibrating machines is chosen such that the frequency of the natural vibrations is lower than the frequency of the exciting force resulting from unbalance and equal to the shaft rotational speed. In this case, the forced vibrations of the machine occur in the post-resonance region, where the amplitude-frequency response graph has a horizontal section and the vibration amplitude does not depend on the load. This provides nominal operating modes regardless of the change in the mass of the technological load in time. In the operational post-resonance mode, the inertia forces from unbalance and the motion of the screen box are in the opposite directions; this makes the system completely balanced dynamically. In this case, only the static component of the inertia force is transmitted to the supports and bridging; it is equal to $m_{o p . m} \omega_{u}^{2} e$, where $m_{\text {op.m }}$ is the unbalanced mass, $\omega_{u}$ is the rotational speed of the vibration exciter shaft in the operating mode, $e$ is the eccentricity.

(C) Vynohradov B. V., Samusya V. I., Kolosov D. L., 2019
The disadvantage of the post-resonance mode is the need to pass through resonance when starting and stopping the vibrating machine [1].

Analysis of the recent research. In order to avoid the resonance vibration amplitudes in the working element at a critical rotational speed and inadmissibly large dynamic loads on the fixed supporting structure of a vibrating machine, vibrators with self-adjusting weights are used [1].

At present, rubber-cord air springs are being increasingly used as elastic supports. This is explained by the fact that air springs have a number of advantages over metal springs: the dimensions being the same, they possess a greater load bearing capacity and longevity; they allow a relatively easy control of the frequency of natural vibrations in the system.

The constructions of the wide range of rubber-cord air springs with a load bearing capacity of 350 to $230 \cdot 10^{3} \mathrm{~N}$ [2] and their visco-elastic characteristics are discussed [3]. The possibility of creating the hydraulic inertial transducer on the basis of rubber-cord shell [4], vibration and impact dampers is shown; the efficiency of their application during manifold loading is confirmed [5].

In the article [6] the stress and strain state of the composite rubber-chord structures is performed using 
the methods of the composite materials mechanics. Mathematical description is based on the principles of the mechanics of the layered structures with stiff and soft layers. The clutches which have rubber-cord shells as the elastic elements [7] and the stress calculation technique were developed [8].

The efficiency of application of the pneumocylinder clutches in machine drives for uniform distribution of the load between transmission lines, limitation of the amplitudes of impact and resonance oscillations [9], control of torsional oscillations in mechanical systems [10] is shown.

The use of air springs as elastic elements allows a solution of a number of engineering issues aimed at optimization of technological processes and solving problems of vibration protection, and others. For example, it was proposed to optimize the performance of the vibrating screen by automatically controlling the stiffness of the elastic suspension, which is most easily implemented by using air springs [11] as elastic elements, or changing the properties of the air spring, depending on the pneumatic resistance of the orifice plate [12].

In particular, the use of air springs as elastic supports of vibrating machines allows a relatively simple solution of the problem of limiting the amplitudes of resonance vibrations and dynamic loads transmitted to the stationary supporting structures of a vibrating machine at a critical rotational speed of the shaft.

The objective of the study is to develop and justify a method for limiting resonance vibrations during startup and shutdown of vibrating machines that incorporate rubber-cord air springs as elastic elements.

Equivalent dynamic models of viscoelastic systems of vibrating machines. We consider two cases: when the working element of the vibrating machine is mounted on a rubber-cord air spring, whose cavity is filled with liquid and is communicated with a hydropneumatic accumulator through an orifice plate (Fig. 1, a); and the case when the cavity of the rubber-cord air spring is filled with compressed air and, through the orifice plate, communicated with an additional volume (Fig. 1, $b$ ).

In the first and second cases, the viscoelastic characteristic of the system is described by the equation [13]

$$
F=S(x)\left[\lambda\left(\frac{d x}{d t}\right)^{2}+\left(p_{0}+p_{m}\right)\left(\frac{V_{G O}}{V_{G O}-\int_{0}^{x} S(x) d x}\right)^{n}-p_{a}\right]
$$

where $F$ is the force taken by the rubber-cord air spring; $S(x)$ is the effective area of the rubber-cord air spring, depending on the $x$ displacement relative to the static equilibrium position; $p_{p . l}=\lambda\left(\frac{d x}{d t}\right)^{2}, \lambda$ is viscous friction coefficient, $p_{p . l}$ is pressure loss caused by hydraulic resistance when the liquid flows from the cavity of the rubber-cord air spring to the hydropneumatic accumulator or the air flows to the additional volume; $V_{G O}$ is a volume of the gas in the pneumatic cavity of the accumulator or in the rubber-cord air spring with an additional volume;

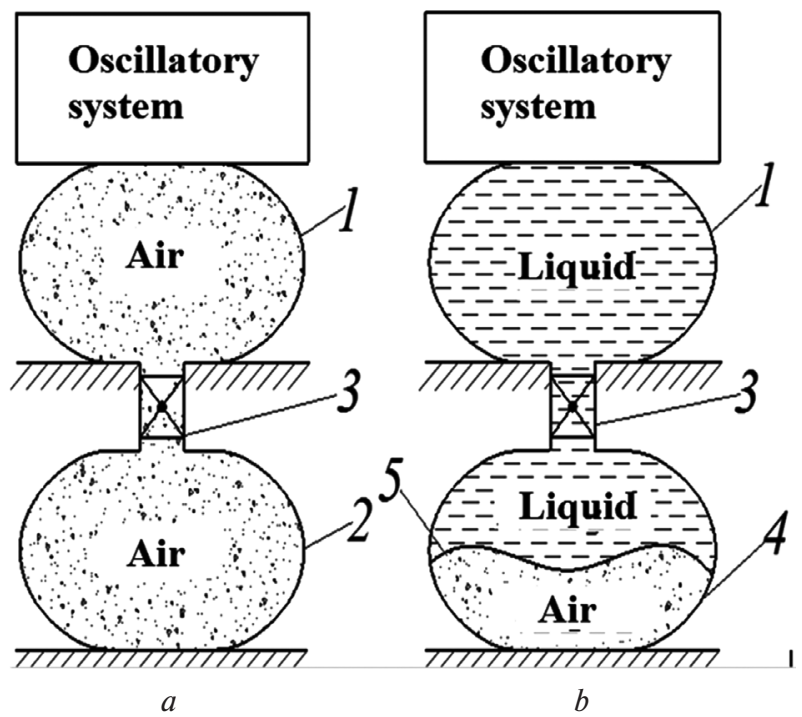

Fig. 1. Viscoelastic system with rubber cord air springs:

$a$ - pneumatic elastic support; $b$ - hydropneumatic elastic support: 1 - rubber cord air spring; 2 - additional volume; 3 - orifice plate; 4 - hydropneumatic accumulator; 5 bladder

$p_{0}$ is atmospheric pressure; $p_{m}$ is excess gas pressure in the rubber-cord air spring or hydropneumatic accumulator under static load; $n$ is the polytropic index.

Experimental studies have shown that the dependence $S(x)$ in the first approximation can be represented by a first degree polynomial

$$
S(x)=a+b x,
$$

where $a, b$ are constants evaluated experimentally.

Considering small vibrations with respect to the static equilibrium position, we may represent the elastic characteristic of the rubber-cord air spring as a linear dependence.

Representing the function (1) as a Taylor series for $x=0$ and restricting to the first two terms, we obtain

$$
F=F_{s t}+c x,
$$

where $F_{s t}$ is elastic force in the static equilibrium position, $c$ is the system stiffness

$$
\begin{gathered}
F_{s t}=a p_{m} \\
c=\left[b p_{m}+\frac{a^{2} n\left(p_{a}+p_{m}\right)}{V_{0}}\right] \approx \frac{a^{2} n\left(p_{a}+p_{m}\right)}{V_{0}} .
\end{gathered}
$$

Fig. 2 shows the elastic characteristics of the H-5 rubber cord air spring: taken from a catalog and obtained by the calculation using formulas (1) and (2) for $b=0, n=1.4$.

For this case, the equivalent dynamic diagrams of the vibration systems under consideration are represented in Fig. 3, where $Q_{0}(\omega)=m_{u} e \omega^{2}$ is the amplitude of the exciting force; $c_{1}, c_{2}$ is the air stiffness in the cavities of the air springs and additional volumes; $\frac{c_{1} c_{2}}{c_{1}+c_{2}}=c$ is equivalent stiffness of the pneumatic system; $\mu$ is viscous 


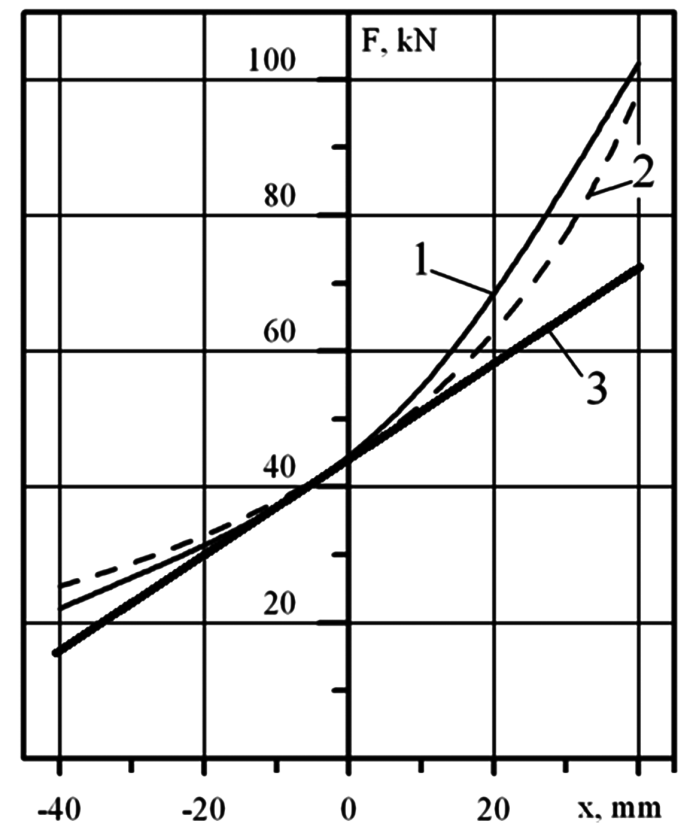

Fig. 2. Elastic characteristic of the $\mathrm{H}-5$ rubber-cord air spring:

1 - catalog; 2, 3 - calculated by the formulas $(1,2)$, respectively

resistance coefficient; $m$ is mass of the vibration system; $x_{1}$ is absolute displacement of mass $m ; x_{2}$ is deformation of elastic connection by stiffness $c_{2}$.

The method for limiting resonance vibrations. Obviously, the magnitude of the vibration amplitudes in the resonance mode may be limited by an increase in the energy dissipation. This problem can be easily solved if the cavities of rubber-cord air springs are connected to additional volumes or a hydropneumatic accumulator by two channels: through a controllable solenoid-operated valve with a relatively small hydraulic resistance and through an orifice plate with a specified hydraulic resistance (Fig. 4).

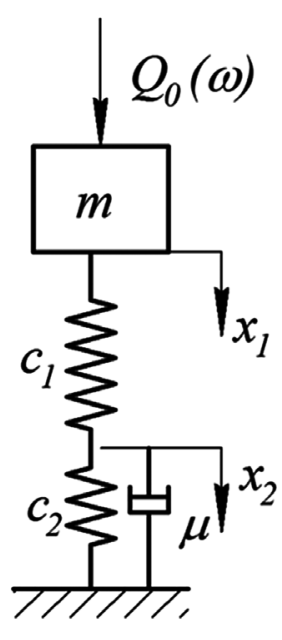

a

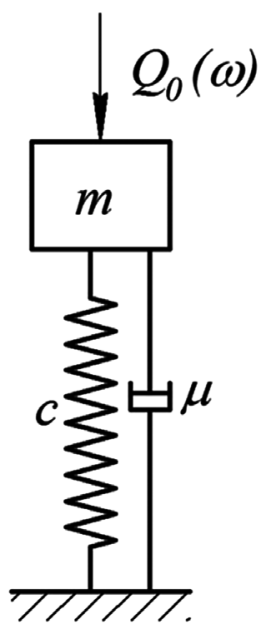

b
Fig. 3. Equivalent dynamic diagrams:

$a, b-$ pneumatic and hydropneumatic viscoelastic systems, respectively [13]

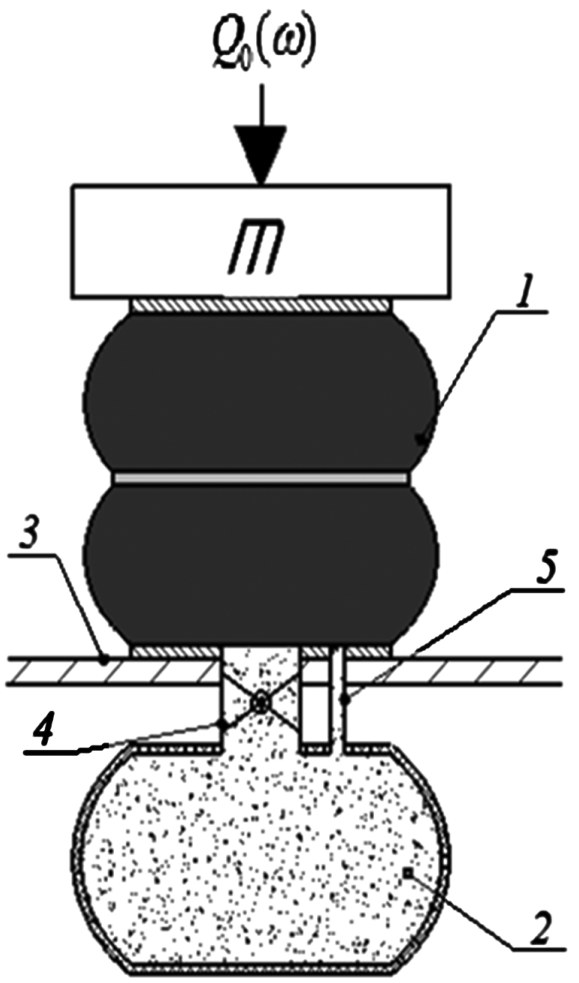

Fig. 4. Schematic diagram of elastic air spring support of the system with an additional volume:

1 - air spring; 2 - additional volume; 3 - fixed support; 4 - solenoid-operated valve; 5 - orifice plate

In the operating mode, the solenoid-operated valves are open, which ensures the minimum forces transmitted to the fixed support structure.

When the vibrating machine starts or stops, the controllable solenoid valves are closed and the communication of the air spring cavities with the additional volumes occurs through the orifice plate. An increase in the resistance force leads to a dissipation of the vibrational energy and to the limitation of the resonance vibration amplitudes at a critical rotational speed of the shaft.

Vibration amplitudes and loads transmitted to the structure of fixed supports. To assess the effectiveness of the proposed method for limiting resonance vibrations and dynamic loads transmitted to the structure of fixed supports during the start-up and shutdown of the vibrating machine, we consider the worst case where the resonant vibrations are of a steady nature.

Differential equations for vertical vibrations of a vibrating machine mounted on rubber-cord air springs, the cavities of which are filled with compressed air and communicated with additional volumes in accordance with the equivalent dynamic diagram shown in Fig. 3, $a$ have the following form

$$
\begin{gathered}
m \ddot{x}_{1}=-c_{2}\left(x_{1}-x_{2}\right)+m_{u} e \omega^{2} \sin \omega t \\
c_{1}\left(x_{1}-x_{2}\right)=\mu \dot{x}_{2}+c_{2} x_{2},
\end{gathered}
$$

where $\mu$ is coefficient of viscous friction force in the orifice plate; $x_{1}$ is absolute displacement of the screen box; $x_{2}$ is deformation of the elastic connection of the additional volume. 
The system of equations (3) may be represented by a third-order differential equation

$$
\dddot{x}_{2}+\frac{c_{1}+c_{2}}{\mu} \ddot{x}_{2}+\frac{c_{1}}{m} \dot{x}_{2}+\frac{c_{1} c_{2}}{m \mu} x_{2}=\frac{c_{1}}{\mu} \frac{m_{u}}{m} \omega^{2} e \sin \omega t \text {. }
$$

The solution of equation (4) for steady-state forced vibrations will be sought in the form

$$
x_{2}=A_{2} \sin (\omega t-\beta),
$$

where $A_{2}$ is the amplitude of $x_{2}$ variation, $t$ is time; $\beta$ is a constant.

Substituting (5) into (4), we define

$$
A_{2}=\frac{\frac{m_{u}}{m} \omega^{2} e}{\sqrt{\left(\frac{c_{2}}{m}-\frac{c_{1}+c_{2}}{c_{1}} \omega^{2}\right)^{2}+\left[\omega \frac{\mu}{c_{1}}-\omega^{2}\right]^{2}}} .
$$

Absolute displacement of the vibration system mass is determined from the second equation (5)

$$
x_{1}=\frac{\mu}{c_{1}} \dot{x}_{2}+\frac{c_{1}+c_{2}}{c_{1}} x_{2} .
$$

Substituting $x_{2}$ and $\dot{x}_{2}$ from (5), we define the amplitude of the forced vibrations of the vibrating system mass

$$
A=\frac{\left(\frac{m_{u} \omega^{2} e}{c}\right) \sqrt{1+\left(\frac{\mu \omega}{c_{1}+c_{2}}\right)^{2}}}{\sqrt{\left(1+\frac{\omega^{2}}{k_{1}^{2}}\right)+\left[\frac{\omega \mu m}{c_{1} c_{2}}\left(\frac{c_{2}}{m}-\omega^{2}\right)\right]^{2}}} .
$$

An analysis of expression (8) shows that the vibrating system can produce resonant vibrations at two rotational speeds of the unbalanced mass shaft, depending on the resistance force of the orifice plate.

With a small viscous resistance force in the orifice plate, the frequency of the natural vibrations of the system (the critical rotational speed of the unbalanced mass shaft) is equal to

$$
k_{1}=\sqrt{\frac{\tilde{n}}{m}} .
$$

With a large force of viscous resistance, the effect of chocking the additional volume occurs. The natural frequency of the system and the critical rotational speed of the unbalanced mass shaft, in this case, will be

$$
k_{2}=\sqrt{\frac{\tilde{n}_{1}}{m}} .
$$

The amplitude-frequency response for these two particular cases is obtained by assuming $\mu=0$ and $\mu=\infty$, respectively, in expression (8)

$$
A_{1}=\frac{\frac{m_{u}}{c} \omega^{2} e}{1-\frac{\omega^{2}}{k_{1}^{2}}}
$$

$$
A_{2}=\frac{\frac{m_{u}}{c} \omega^{2} e}{1-\frac{\omega^{2}}{k_{2}^{2}}}
$$

The effectiveness of limiting the resonance amplitudes and the dynamic loads transmitted to the construction of the fixed support during the start-up and shutdown is considered below, using the example of a GIS-52 vibrating screen. The following initial data are used in the calculations: shaft rotational speed is $900 \mathrm{rpm}$; screen mass with material is 12.5 tons; the unbalanced mass is $132 \mathrm{~kg}$.

Fig. 5 shows the amplitude-frequency response of the vibrating screen to the vertical vibrations $(a)$ and the force transmission coefficients $(b)$ for different throttling depths.

The force transmitted to the supports and bridging will be evaluated by the force transmission coefficient equal to $\frac{F_{\max }}{m_{u} \omega_{o p . m}^{2} e}$, where $F_{\max }$ is the maximum force; $m_{u} \omega_{o p . m} e$ is the amplitude of the exciting force in the op-
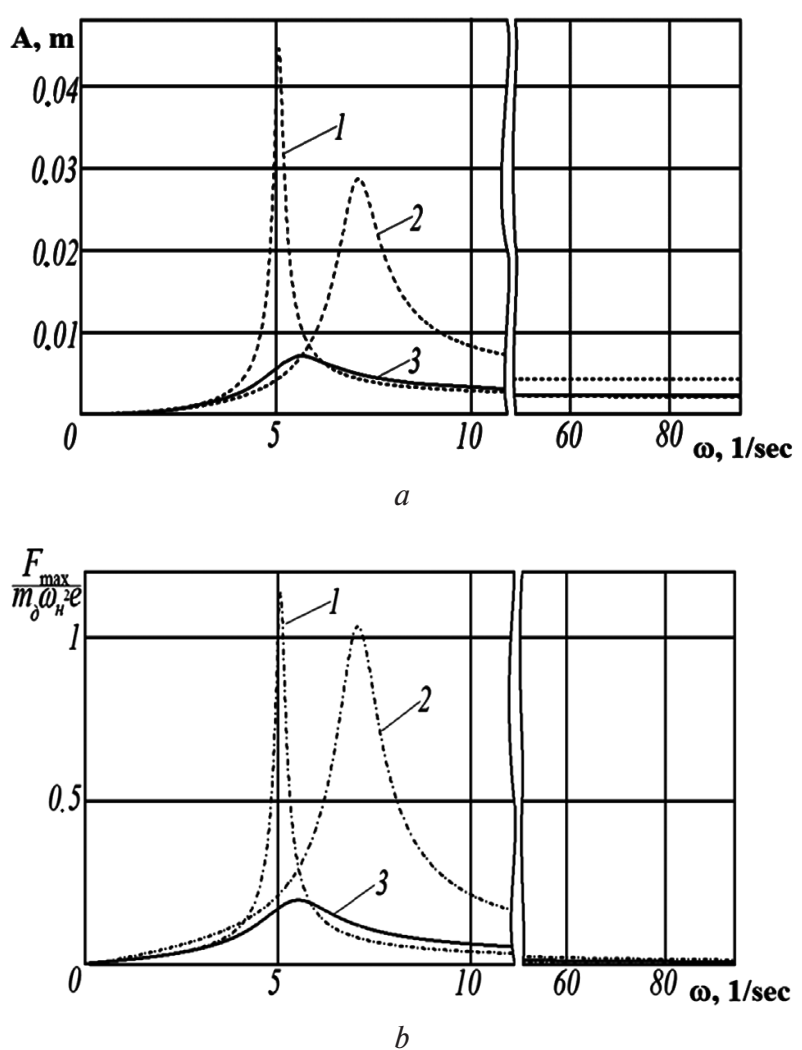

Fig. 5. Amplitude-frequency response of the vibrating screen to vertical vibrations (a) and the force transmission coefficients (b) with a pneumatic elastic support used:

$A$ - the amplitude of the forced vibrations; $\omega$ is rotational speed of the unbalance shaft; $\frac{F_{\max }}{m_{u} \omega_{o p . m}^{2} e}$ is transmission co-

efficient: 1 - solenoid valve is open at $\mu=10000 \mathrm{~N} \cdot \mathrm{sec} / \mathrm{m}$; $2,3-$ solenoid valve is closed at $\mu=120000 \mathrm{~N} \cdot \mathrm{sec} / \mathrm{m}$ and $\mu=1200000 \mathrm{~N} \cdot \mathrm{sec} / \mathrm{m}$ respectively 
erating mode. In this case, the force transmission coefficient shows how many times the force transmitted to the fixed support and bridging is greater than the maximum amplitude of the exciting force that acts under the nominal operating conditions.

The force transmitted to the structure of the fixed support, is

$$
F=\mu \dot{x}_{2}+c_{2} x_{2}
$$

Substituting the values of $x$ and $\dot{x}$, we determine the maximum force and force transmission coefficient depending on the rotational speed of the shaft

$$
\frac{F_{\max }}{m_{u} \omega_{o p . m}^{2} e}=\frac{\omega}{\omega_{o p . m}} \frac{\sqrt{1+\left(\frac{\mu \omega}{c_{2}}\right)^{2}}}{\sqrt{\left(1-\frac{\omega^{2}}{k_{1}^{2}}\right)^{2}+\left[\frac{\omega \mu m}{c_{1} c_{2}}\left(\frac{c_{1}}{m}-\omega^{2}\right)\right]^{2}}}
$$

The calculated dependence of the force transmission coefficient on the shaft rotational speed for different viscous resistance forces is shown in Fig. 5, $b$.

For comparison, we consider the viscoelastic system shown in Fig. 1, $b$.

The amplitude of the forced vibrations and the transmission coefficient in this case are described by the expressions

$$
\begin{gathered}
A=\frac{\frac{m_{u} \omega^{2} e}{c}}{\sqrt{\left(1-\frac{\omega^{2}}{k^{2}}\right)^{2}+4 h^{2} \frac{\omega^{2}}{k^{2}}}} ; \\
\frac{F_{\max }}{m_{u} \omega^{2} e}=\frac{\omega}{\omega_{o p . m}} \frac{\sqrt{1+h^{2} \frac{\omega^{2}}{k^{2}}}}{\sqrt{\left(1-\frac{\omega^{2}}{k^{2}}\right)+4 h^{2} \frac{\omega^{2}}{k^{2}}}} .
\end{gathered}
$$

Fig. 6 shows the amplitude-frequency response of the vibrating screen to the vertical vibrations $(a)$ and the force transmission coefficients $(b)$ for different throttling depths.

Conclusions. The use of rubber-cord air springs as elastic elements allows a relatively simple solution to the problem of limiting the amplitudes of vibrations and the dynamic loads transmitted to the fixed support structure during the vibrating machine start-up and shutdown. In this case, the vibrating system, where air springs with additional volumes are used as elastic supports, exhibits the following features:

- at relatively low viscous resistance forces determined by the parameters of the orifice through which the cavity of the rubber-cord air spring is communicated with an additional volume, the start-up/shutdown resonance vibrations may occur in the vibrating machine at the unbalance shaft rotational speed of $\omega_{p}=\sqrt{c / m}$, where $c$ is equivalent stiffness of the pneumatic system;

- an increase in the viscous resistance force leads to a decrease in the amplitude of resonance vibrations and transmission coefficients that characterize the dynamic load transmitted to the fixed support. There is a value of

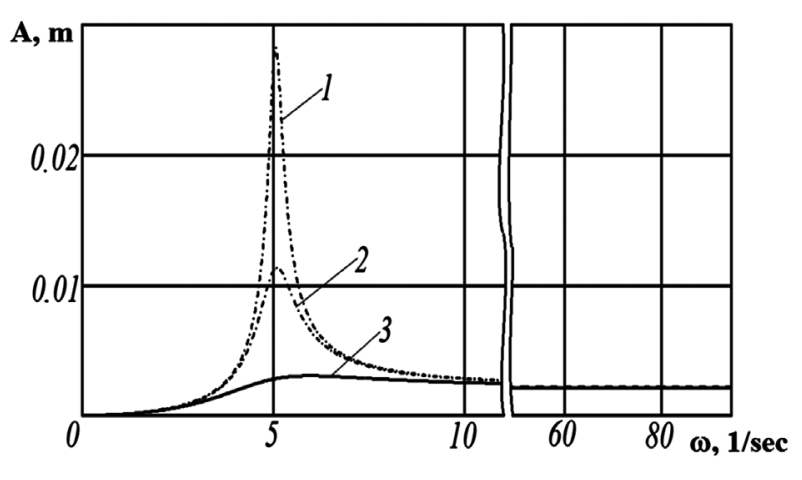

$a$

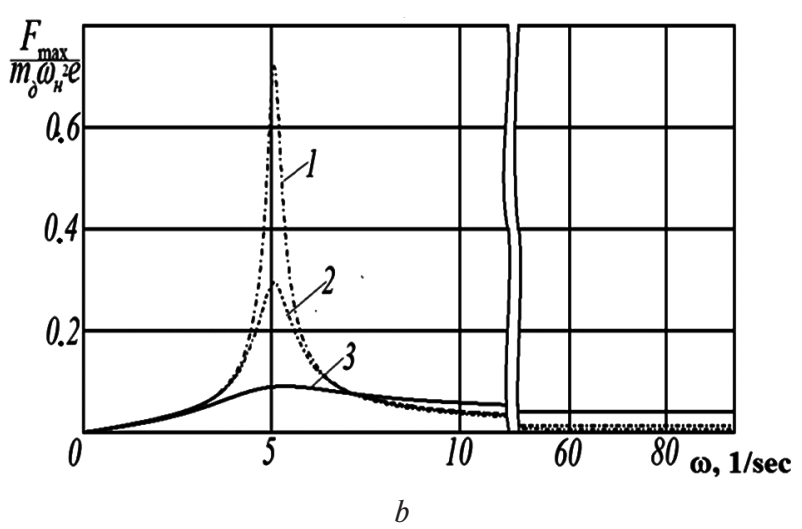

Fig. 6. Amplitude-frequency response of the vibrating screen to vertical vibrations (a) and the force transmission coefficients (b) with a hydropneumatic elastic support used:

$A$ - the amplitude of forced vibrations; $\omega$ is rotational speed of the unbalanced mas shaft; $\frac{F_{\max }}{m_{u} \omega_{o p . m}^{2} e}$ is transmission coefficient: 1 - solenoid valve is fully open $\mu=50 \mathrm{~N} \cdot \mathrm{sec} / \mathrm{m}$; 2,3 - the solenoid valve is closed at the throttling depth of $\mu=125 \mathrm{~N} \cdot \mathrm{sec} / \mathrm{m}$ and $\mu=500 \mathrm{~N} \cdot \mathrm{sec} / \mathrm{m}$ respectively

the viscous resistance force at which the amplitude of the resonance vibrations and the dynamic loads transmitted to the fixed support at the critical rotational speed take the minimum values;

- a further increase in the viscous resistance force does not reduce the amplitudes and dynamic loads, but leads to a shift of the resonance mode toward an increase in the critical rotational speed of the unbalance shaft. At a certain value of the viscous resistance force, the effect of chocking the orifice is observed, and resonance vibrations occur at the unbalance shaft rotational speed equal to $\omega_{p}=\sqrt{c_{2} / m}$, where $c_{2}$ is the stiffness of the air spring filled with compressed air.

\section{References.}

1. Bogdanov, O.S., 1982. Reference-book on ore processing. V.1. Preparatives. Moscow: Nedra [online]. Available at: <http://www.twirpx.com/file/43616/> [Accessed 11 December 2017].

2. FGUP "FNPTs "Progress". Pneumoelements with rubber-cord casing: catalog [online]. Available at: $<$ http:// www.progress-omsk.ru/constructor.php?act=group 5> [Accessed 27 September 2017]. 
3. Firestone Industrial Products Company, LLC-2017, 2017. Firestone air springs: catalogs [online]. Available at: <http://www.progress-omsk.ru/constructor.php?act= group5 $>$ [Accessed 25 November 2017].

4. Buryan, Yu. A., Sorokin, V. N., Silkov, M. V. and Galuza, Yu. F., 2015. Hydraulic inertial motion transformer with rubber-cord casing. Omsk Scientific Bulletin, 1(137), pp. 30-33.

5. Shpachuk, V., Chuprynin, A., Suprun, T. and Garbuz, A., 2018. A multifactor analysis of the rail transport car that passes over a joint unevenness with respect to the phases of its motion. Eastern-European Journal of Enterprise Technologies, 1(7(91)), pp. 55-61.

6. Kolosov, D., Dolgov, O. and Kolosov, A., 2014. Analytical determination of stress-strain state of rope caused by the transmission of the drive drum traction. In: Progressive Technologies of Coal, Coalbed Methane, and Ores Mining, pp. 499-504.

7. Manashkin, L.A., Myamlin, S. V. and Prihodko, V. I., 2007. Vibration absorbers and shock isolators of rail carriages (mathematical models). Monograph [pdf]. Available at: <http://www.library.diit.edu.ua/bitstream/ 123456789/328/2/Manashkin_Myamlin_Prikhodko_ rus.pdf> [Accessed 30 October 2017].

8. Nemchinov, S. and Khristenko, A., 2018. Stressstrain state of pneumatic flexible shaft coupling for ball mill drives. Scientific Journal of Silesian University of Technology. Series Transport, 99, pp. 125-134.

9. Vinogradov, B. V. and Khristenko, A. V., 2016. Flexible couplings with rubber-cord shells in dual pinion mill drives. Naukovyi Visnyk Natsionalnoho Hirnychoho Universytetu, 1, pp. 42-46.

10. Homišin, J., 2011. Controlling torsional vibration of mechanical systems by application of pneumatic flexible shaft couplings. Zeszyty Naukowe Politechniki Śląskiej, Transport, 72, pp. 33-40. DOI: 10.20858/sjsutst.2018.99.12.

11. Bidulya, A.L., Kirikov, A. K., Krasnov, O.G. and Vorobyov, S.A., Russian Railways, 2010. Shake screen. Russia. Pat. 2394654 [online]. Available at: <http:// www.freepatent.ru/patents/2394654 915> [Accessed 11 September 2017].

12. Reydemeyster, A. G., Kivisheva, A. V. and Shykunov, O.A., 2016. Dependence of air spring parameters on throttle resistance. Science and Transport Progress. Bulletin of Dnipropetrovsk National University of Railway Transport, 2(62), pp. 148-157.

13. Vinogradov, B. V., 2011. On dynamic characteristics of visco-elastic systems with rubber-cord casing. Vibration in engineering and technology, 1(61), pp. 20-24.

\section{Обмеження коливань вібраційних машин під час пуску та зупинки}

\section{Б. В. Виноградов ${ }^{1}$, В. І. Самуся², Д. Л. Колосов ${ }^{2}$}

1 - Державний вищий навчальний заклад „Український державний хіміко-технологічний університет“, м. Дніпро, Україна, e-mail: borvvin@gmail.com

2 - Національний технічний університет „Дніпровська політехніка“, м. Дніпро, Україна, e-mail: vsamusya@ gmail.com; evolyuta@gmail.com
Мета. Розробка способу та обгрунтування ефективності обмеження резонансних коливань при пуску й зупинці вібраційних машин при використанні гумо-кордних оболонок як пружних елементів.

Методика. Розглядаються пружно-в'язкі моделі двох систем: перша включає гумо-кордну оболонку, заповнену стисненим повітрям і сполучену з додатковим об'ємом повітря через дросельний отвір; друга містить гумо-кордну оболонку, порожнина якої заповнена рідиною та сполучена через дросель 3 гідропневматичним акумулятором. Для даних пружно-в'язких систем представлені лінеаризовані еквівалентні динамічні схеми та складені диференціальні рівняння руху. Далі розглянуто спосіб обмеження резонансних коливань при розгоні й зупинці вібраційних машин. Ефективність обмеження резонансних коливань і зусиль, переданих на конструкції нерухомих опор, досліджена на прикладі вібраційного грохоту. Розглянуто найгірший випадок, коли резонансні коливання носять усталений характер. Отримані амплітудно-частотні характеристики й коефіцієнти, що характеризують передачу динамічних навантажень на конструкції нерухомих опор за різних сил в'язкого опору, визначених параметрами дроселя.

Результати. Розроблені еквівалентні схеми пружно-в'язких систем, що містять гумо-кордні оболонки, і математична модель, що описує змушені коливання, запропонований спосіб обмеження коливань і навантажень, що передаються на конструкції нерухомих опор, під час пуску та зупинки вібраційних машин. Обгрунтована ефективність запропонованого способу.

Наукова новизна. Науково обгрунтовано, що застосування гумо-кордних оболонок як пружних елементів вібраційних машин дозволяє ефективно обмежувати резонансні коливання й динамічні навантаження, що передаються на конструкції нерухомих опор.

Практична значимість. Це дозволяє обмежити амплітуди резонансних коливань грохоту та знизити динамічні навантаження на опори вібромашин.

Ключові слова: вібраційна машина, гумо-кордна оболонка, пружно-в'язка система, резонансні коливання, віброзахист

\section{Ограничение колебаний вибрационных машин при пуске и остановке}

\section{Б. В. Виноградов ${ }^{1}$, В. И. Самуся², Д. Л. Колосов ${ }^{2}$}

1 - Государственное высшее учебное заведение „Украинский государственный химико-технологический университет“, г. Днепр, Украина, e-mail: borvvin@gmail.com 2 - Национальный технический университет „Днепровская политехника“", г. Днепр, Украина, e-mail: vsamusya@ gmail.com; evolyuta@gmail.com

Цель. Разработка способа и обоснование эффективности ограничения резонансных колебаний при пуске и остановке вибрационных машин при 
использовании в качестве упругих элементов резино-кордных оболочек.

Методика. Рассматриваются упруго-вязкие модели двух систем: первая включает резинокордную оболочку, заполненную сжатым воздухом и сообщающуюся с дополнительным объёмом воздуха через дроссельное отверстие; вторая содержит резинокордную оболочку, полость которой заполнена жидкостью и сообщающуюся через дроссель с гидропневматическим аккумулятором. Для данных упруговязких систем представлены линеаризованные эквивалентные динамические схемы и составлены дифференциальные уравнения движения. Далее рассмотрен способ ограничения резонансных колебаний при разгоне и остановке вибрационных машин. Эффективность ограничения резонансных колебаний и усилий, передаваемых на конструкции неподвижных опор, исследована на примере вибрационного грохота. Рассмотрен наихудший случай, когда резонансные колебания носят установившийся характер. Получены амплитудно-частотные характеристики и коэффициенты, характеризующие передачу динамических нагрузок на конструкции неподвижных опор при различных силах вязкого сопротивления, определяемых параметрами дросселя.
Результаты. Разработаны эквивалентные схемы упруго-вязких систем, содержащих резинокордные оболочки, и математическая модель, описывающая вынужденные колебания, предложен способ ограничения колебаний и нагрузок, передаваемых на конструкции неподвижных опор при пуске и остановке вибрационных машин. Обоснована эффективность предлагаемого способа.

Научная новизна. Научно обосновано, что применение резино-кордных оболочек в качестве упругих элементов вибрационных машин позволяет эффективно ограничивать резонансные колебания и динамические нагрузки, передаваемые на конструкции неподвижных опор.

Практическая значимость. Это позволяет ограничить амплитуды резонансных колебаний грохота и снизить динамические нагрузки на опоры вибромашин.

Ключевые слова: вибрационная машина, резинокордная оболочка, упруго-вязкая система, резонансные колебания, виброзащита

Рекомендовано до публікації докт. техн. наук I. М. Кузяєвим. Дата надходження рукопису 23.11.17. 